\title{
PENGARUSUTAMAAN MODAL SOSIAL DALAM PEMBANGUNAN PERDESAAN
}

\author{
Abdul Rahman \\ abdul.rahman8304@unm.ac.id \\ Nurlela \\ nurlela@unm.ac.id \\ Rifal \\ rifalmattirodeceng@gmail.com
}

Fakultas Ilmu Sosial, Universitas Negeri Makassar

\begin{abstract}
This article discusses the importance of social capital in rural development. Social capital is deemed necessary in rural development activities because historical data shows that development carried out by the government of the Republic of Indonesia, especially during the New Order administration tended to neglect community participation, even though it was the community who would utilize the development results. Entering the era of reform, the direction of rural development underwent a paradigm shift, in which the community is no longer placed as an object, but has been positioned as the subject of development, which is more popularly known as development with the botton up approach. The paradigm is then elaborated on empirical reality by placing Tompobulu Village community as a locus of research. The results showed that the development activities in this village could run in accordance with expectations because they got the support of the community who synergized with the government, and placed social capital as the basic capital in implementing development.
\end{abstract}

Keywords: Social Capital, Rural Development 


\section{Pendahuluan}

Salah satu tugas pemerintah Republik Indonesia yang diamanahkan dalam pembukaan UUD 1945 sebagai dasar pembentukan Negara Kesatuan Republik Indonesia ialah memajukan kesejahteraan umum (Fahruddin, 2012). Hal tersebut kemudian diperkuat oleh Undang-Undang Otonomi Daerah Nomor 23 Tahun 2014 yang mengamanahkan kepada daerah untuk meningkatkan kesejahteraan sosial (Muryanto dkk, 2019). Kesejahteraan sosial dapat terwujud jika pemerintah secara serius menggalakkan proses pembangunan. Namun harus dipahami bahwa pembangunan untuk kesejahteraan bukan hanya tanggung jawab pemerintah, akan tetapi merupakan tanggung jawab seluruh komponen bangsa, dalam hal ini adalah masyarakat, dunia usaha dan masyarakat akademik (perguruan tinggi).

Pembangunan merupakan proses yang menyejarah. Sebuah proses yang berlangsung secara berkelanjutan dalam dimensi ruang dan waktu. Pembangunan merupakan usaha sadar manusia untuk melakukan perubahan ke arah yang lebih baik. Dengan demikian pembangunan tmerupakan proses penalaran dalam rangka menciptakan kebudayaan dan peradaban manusia (Jamaluddin, 2016).
Pembangunan akan berlangsung secara berkelanjutan seiring dengan semakin berkembangnya peradaban umat manusia, sebab antara manusia dan pembangunan memiliki keterkaitan yakni manusia sebagai subjek dan objek pembangunan. Keterkaitan antara manusia dengan pembangunan menunjukkan adanya serangkaian upaya atau langkah untuk memajukan kondisi masyarakat sebuah kawasan atau negara dengan konsep pembangunan tertentu (Tjokrowinoto, 2004). Dalam konteks Indonesia, kata pembangunan sudah menjadi kata kunci bagi segala hal. Secara umum, kata ini diartikan sebagai usaha untuk memajukan kehidupan masyarakat dan warganya. Seringkali, kemajuan yang dimaksud terutama adalah kemajuan material. Maka, pembangunan seringkali diartikan sebagai kemajuan yang dicapai oleh sebuah masyarakat di bidang ekonomi (Budiman, 1996).

Lebih lanjut Gunawan Sumodingrat dan Ari Wulandari menguraikan bahwa pembangunan sebagai usaha untuk meningkatkan pendapatan per kapita, berarti sebagai suatu usaha, pembangunan merupakan tindakan aktif yang harus dilakukan oleh suatu negara untuk meningkatkan pendapatan per kapita (Sumodingrat, G 
\& Wulandari, 2016). Dengan demikian, sangat dibutuhkan peran serta masyarakat, pemerintah, dan semua elemen yang terdapat dalam suatu negara untuk berpartisipasi aktif dalam proses pembangunan. Pembangunan bukan hanya dibebankan kepada pemerintah, tetapi perlu juga ada keterlibatan masyarakat untuk mewujudkan kesejahteraan bersama. Kesejahteraan masyarakat mencerminkan perbaikan dalam bidang kehidupan. Salah satu upaya untuk mencapai kesejahteraan ialah dengan cara menggiatkan pembangunan di wilayah perdesaan.

Ketika Indonesia sudah memasuki era modernisasi dan industrialisasi, pembahasan mengenai pembangunan masyarakat desa masih terus berlangsung baik pada tataran birokrasi pemerintahan maupun dalam lingkungan akademik perguruan tinggi. Menurut Sunyoto Usman, pembangunan masyarakat desa masih relevan dibahas karena secara umum, wilayah Indonesia masih didominasi oleh daerah perdesaan, walau tak bisa dinafikkan akan kemajuan kota yang begitu pesat. Kondisi ini akan berlangsung relatif lama. Benar bahwa di beberapa daerah ciri perdesaan itu susut perlahan bersamaan dengan proses industrialisasi dan urbanisasi, akan tetapi itu tidak berarti hilang sama sekali. Ciri perdesaan tersebut bahkan masih akan bertahan sedemikian rupa sehingga mempengaruhi arah dan sifat perkembangan kota dalam kerangka Negara Kesatuan Republik Indonesia yang sedang giat melakukan program pembangunan nasional (Usman, 2010).

Dalam konteks pembangunan nasional, wilayah perdesaan memiliki posisi dan peran yang cukup strategis. Hal tersebut disebabkan karena penduduk Indonesia sebagai penggerak dan sasaran pembangunan pada umumnya bermukim di wilayah perdesaan. Selain itu, wilayah perdesaan memiliki peranan penting dalam mewujudkan stabilitas keamanan nasional. Secara teoritik keamanan nasional suatu negara dapat terwujud jika masyarakat, termasuk masyarakat perdesaan dapat memperoleh penghidupan yang layak untuk melestarikan keberlanjutan kehidupan keluarga mereka.

Menyadari bahwa wilayah perdesaan memiliki arti yang sangat penting dalam keberlangsungan dan kedaulatan Indonesia sebagai negara bangsa, maka pemerintah sangat menaruh perhatian yang cukup serius dalam pengelolaan dan pembangunan 
wilayah perdesaan dalam berbagai sektor. Keseriusan tersebut ditunjukkan oleh pemerintah yang tergabung dalam kabinet kerja dengan membentuk Kementerian Desa, Pembangunan Daerah Tertinggal dan Transmigrasi. Berdasarkan Permendes No.6 Tahun 2015, kementerian ini bertugas untuk menyelenggarakan urusan pemerintahan di bidang pembangunan desa dan kawasan perdesaan, pemberdayaan masyarakat desa, percepatan pembangunan daerah tertinggal, dan transmigrasi sebagai bagian dari urusan pemerintahan Negara Kesatuan Republik Indonesia.

Pemerintah

penyelenggara negara sebagai pada kenyataannya selalu menyatakan bahwa kebijakan pembangunan dimaksudkan untuk mewujudkan kemajuan dan kemakmuran rakyat. Tetapi yang sering dilupakan, apakah proses pembangunan tersebut benar-benar telah di dalami dan dipandu dengan nilai-nilai dasar negara sehingga pengerjaannya tidak mencederai sekelompok masyarakat tertentu. Hal inilah yang menjadi pertanyaan-pertanyan etis wajib untuk terus dikumandangkan demi menjaga kemaslahatan bersama. Dari sinilah unsur etika bisa masuk dan sangat berperanan penting dalam menghitung setiap nisbah pembangunan yang dilaksanakan (Yustika, 2003).

Menurut Soedjatmoko, diskusi mengenai etika pembangunan ini menjadi sedemikian penting jika dilihat kenyataan bahwa proses pembangunan bukanlah proses teknokratis dan birokratis semata. Sebaliknya, suatu pembangunan tidak bisa dilepaskan dari realitas kekuasaa dan politik (Winarno, 2013). Akan tetapi, jika pembangunan dilaksanakan dengan mengedepankan dimensi kekuasaan dan mengabaikan aspirasi masyarakat, maka akan muncul ketimpangan. Fakta menunjukkan bahwa Pemerintah Orde Baru dalam kebijakannya telah menjadikan pembangunan ekonomi sebagai basis bagi legitimasi kekuasaannya. Atas nama pembangunan ekonomi itu pula, pemerintah Orde Baru menunda pemenuhan terhadap hak-hak sipil dan politik warga negaranya. Saat itu, siapa saja yang berani berseberangan dengan kebijakan pemerintah, segera akan berhadapan dengan alat represi negara yang secara sempurna dijalankan oleh tentara (Baswir, 1999).

Kondisi tersebut mencerminkan bahwa pemerintah Orde Baru dalam menjalankan kebijakannya bersifat otoriter. Tidak seorang pun yang diberi kesempatan untuk memprotes dan 
menolak kebijakan yang telah ditetapkan pemerintah. Demikian pula dalam kegiatan pembangunan, masyarakat ditempatkan sebagai objek. Semua program-program pembangunan diatur oleh pemerintah pusat. Pemerintah daerah dan masyarakat tinggal menerima dan melaksanakan program pembangunan yang telah dirancang oleh pemerintah pusat. Konsep seperti ini dikenal dengan program pembangunan yang menggunakan pendekatan top down

Susah dipungkiri bahwa pendekatan top down yang diterapkan oleh pemerintah Orde Baru dalam pelaksanaan pembangunan menghasilkan pertumbuhan ekonomi secara fantastis dalam ukuran kuantitas. Tetapi keberhasilan tersebut tidak dibarengi oleh kemajuan lain dalam bidang sosial sehingga muncul ketimpangan dalam kehidupan masyarakat. Pada beberapa daerah muncul ketimpangan karena ketidakmampuan dan ketidaksiapan daerah untuk mengimplementasikan konsep pembangunan yang telah dirancang oleh pemerintah pusat. Kegagalan untuk menerapkan program pembangunan yang dirancang oleh pemerintah pusat disebabkan oleh kurangnya kemampuan teknis dan kemampuan sumber daya manusia aparat pemerintah daerah. Selain itu, ada ketidaksesuaian antara program pembangunan yang digelontorkan oleh pemerintah pusat dengan kondisi daerah dan kehendak masyarakat, sebab dalam penyusunan program masyarakat tidak dilibatkan. Hal tersebut kemudian memunculkan sikap apatis dari masyarakat terhadap kegiatan pembangunan, sebab mereka merasa tidak memiliki sangkut paut dengan kegiatan tersebut. Pada akhirnya, kegiatan pembangunan telah dilaksanakan tetapi tidak mendatangkan hasil dan manfaat yang maksimal terhadap kehidupan masyarakat.

Pembangunan

dengan

pendekatan top down yang dicanangkan oleh pemerintahan Orde Barutelah menyebabkan hilangnya mekanisme kontrol sosial tradisional pada wilayah perdesaan. Akan tetapi, masih ada lembaga lokal yang otonom tetap ada di desa-desa di Indonesia yang memiliki kemampuan untuk memobilisasi sumber daya desa untuk kemaslahatan bersama. Kemampuan yang paling kuat berada di tingkat dusun, di mana kedekatan fisik, keseragaman sosial yang tinggi dan ikatan kekerabatan menciptakan komunitas alamiah. Sebaliknya kemampuan tersebut lemah di tingkat 
desa karena desa merupakan unit administratif standar yang dipaksakan di bawah kendali Orde Baru. Desa kerap kali terpencar-pencar secara fisik dan mengalami keretakan secara sosial. Para administratornya berorintasi untuk menerapkan kebijakan-kebijakan dari atas dan menyenangkan atasan mereka, kebiasaan Orde Baru yang terus bertahan di banyak kawasan perdesaan di masa reformasi (Angelis, 2016). Kemampuan untuk tetap bertahan dari penetrasi pembangunan Orde Baru yang mengusung paradigma modernisasi membuat kelompok-kelompok adat perdesaan untuk tetap hidup bersahaja, terjadi keharmonisan antara manusia dengan manusia, dan manusia dengan alam sekitar (flora dan fauna). Hal tersebut dapat dilihat pada berbagai komunitas adat yang ada di Sulawesi Selatan, misalnya Komunitas Adat Kajang di Kabupaten Bulukumba, Komunitas Adat Karampuang di Kabupaten Sinjai dan Komunitas Adat Cerekang di Kabupaten Luwu. Hingga saat ini, ketiga komunitas adat itu tetap bertahan dan memiliki jasa dalam pelestarian lingkungan, khususnya pelestarian sumber daya hutan.

Kondisi pembangunan yang belum tentu mendatangkan keuntungan secara maksimal terhadap kehidupan masyarakat diperkuat oleh Warjio. Pembangunan adalah sebuah paradoks global yang sarat dengan kepentingan politik. Pembangunan dan hasil-hasilnya belum mencapai tujuan sebagaimana diharapkan oleh banyak pihak. Paradoks pembanguan yang diamaksud oleh Warjio ialah sebuah kondisi di mana apa yang diinginkan ataupun ditargetkan dalam pembangunan tidak sebagaimana yang diinginkan dan malah timbul masalah yang menyertaninya. Pembangunan terkadang meminggirkan nilai-nilai lokalitas, tetapi juga melahirkan persoalan baru dalam soal kebijakan pembangunan. Melalui paradoks pembangunan ini, masyarakat selalu diperhadapkan pada dua situasi yang saling bertolak belakang. Misalnya, alam melimpah yang dimiliki oleh suatu negara dan kemudian diolah atas nama pembangunan namun yang terjadi justru alam menjadi rusak dan menimbulkan persoalan politik yang tidak berkesudahan. Kebijakan pembangunan justru diikuti oleh kemunculan pengangguran, bencana alam, dan kemiskinan (Warjio, 2016).

Berdasarkan pada pengalaman tersebut, maka Adrinof A. Chaniago salah seorang peminat dan pemerhati masalah pembangunan menawarkan untuk tidak lagi berfokus pada pendekatan 
pembangunan yang sifatnya top down, akan tetapi sudah saatnya merubah orientasi pembangunan yang sifatnya botton up. Pendekatan ini merupakan pola pendekatan perencanaan pembangunan yang mendorong masyarakat untuk berperan aktif dalam proses pembangunan. Nuansa pembangunan kelihatan benar-benar menyerap aspirasi masyarakat sebab mereka ditempatkan sebagai pelaksana dan sasaran pembangunan (Chaniago, 2012).

Gagasan pembangunan yang menempatkan masyarakat sebagai subjek dan objek perlu mengarusutamakan modal sosial. Menurut kajian cermat yang dilakukan oleh Haridison modal sosial sangat penting dalam pelaksanaan pembangunan. Kehadiran modal sosial dalam pembangunan dapat meningkatkan kesadaran individu tentang banyaknya peluang yang dapat dioptimalkan untuk kepentingan masyarakat, misalnya kemampuan untuk menyelesaikan kompleksitas permasalahan kehidupan masyarakat, memberikan stimulus kepada masyarakat untuk bergerak melakukan perubahan secara masif, menumbuhkan kesadaran bersama untuk memperbaiki kualitas tatanan kehidupan masyarakat dan mencari kesempatan yang dapat dimanfaatkan untuk mewujudkan kesejahteraan (Haridison, 2017).

\section{Pembahasan}

\section{Pembangunan Perdesaan: Sebuah} Tinjauan Historis

Berkaitan dengan kegiatan pembangunan wilayah perdesaan, A.T Mosher menguraikan bahwa tujuan pembangunan perdesaan berfokus pada upaya untuk menumbuhkan sektor pertanian, dan persatuan nasional, yaitu mewujudkan masyarakat dalam sebuah negara pada pola utama kehidupan yang bernuansa kesejahteraan, dan menciptakan keadilan ekonomi dimana seluruh pendapatan negara dapat didistribusikan dan dinikmati oleh seluruh masyarakat (Mosher, 1969) . Sementara itu Prijono Tjiptoherijanto merumuskan bahwa pembangunan perdesaan dimaksudkan sebagai upaya untuk mengentaskan masyarakat dari belenggu kemiskinan dengan cara membuka kesempatan berusaha, memperkuat ketahanan keluarga, memperkuat gotong royong, penyediaan modal usaha, dan mendorong partisipasi masyarakat dalam berbagai bidang sosial kemasyarakatan.

Hingga saat ini, permasalahan klasik yang melanda perdesaan ialah masalah kemiskinan (Tjiptoherijanto, 1997). 
Wilayah perdesaan pada umumnya ditandai oleh karakteristik ketertinggalan perkembangan kehidupan sosial dan ekonomi, seperti rendahnya tingkat pendidikan, produktivitas, pendapatan, gizi, terbatasnya lapangan kerja, sulitnya akses terhadap modal untuk meningkatkan produktivitas ekonomi serta kesejahteraan hidup yang lemah. Keadaan inilah yang menjadi sasaran pembangunan karena kehidupan mereka perlu ditingkatkan terutama untuk mengatasi kemiskinan masyarakat di perdesaan. Pengentasan kemiskinan merupakan kegiatan multidimensi, tidak hanya terkait dengan sasaran bidang pendidikan, tetapi juga sasaran pemenuhan kebutuhan dasar manusia yang harus ditangani secara terpadu (Rustanto, 2015).

Banyak di wilayah perdesaan yang masyarakatnya hidup dalam garis kemiskinan. Hidup mereka sangat tergantung pada kemurahan alam dengan penghasilan subsisten (Hutagalung, 2012). Subsistensi dan orang desa merupakan gambaran tentang kondisi sosial masyarakat pedesaan, sebagai lingkaran setan antara kemiskinan dan tata nilai. Orang desa sudah terbiasa berada pada kondisi ketidakberdayaan bahkan sudah menjadi kebiasaan dan melembaga hingga berkembang menjadi tata nilai atau norma umum. Sementara subsistensi adalah kegiatan usaha tani yang hanya cukup untuk kepentingannya sendiri atau cukup untuk kebutuhan makan sehari-hari saja (Yuliati, 2003). Kondisi yang demikian itu kemudian ditindaklanjuti oleh pemerintah Orde Baru dengan menerbitkan UndangUndang nomor 5/1979 yang mengatur tata kelola pemerintahan desa. Maksud dari UU tersebut ialah untuk memberdayakan pemerintah desa dalam menggerakkan masyarakat untuk ikut berpartisipasi dalam pembangunan perdesaan agar terbebas dari belenggu kemiskinan.

Secara konseptual, Indonesia telah mempunyai arah pembangunan pedesaan dan pertanian yang jelas sejak awal Orde Baru, dan konsep tersebut dimatangkan dalam berbagai cetak biru pembangunan pedesaan, dalam GarisGaris Besar Haluan Negara (GBHN) dan Repelita (Jamal, 2009). Pada masa awal Orde Baru, Indonesia merupakan sebuah negeri miskin, seperti banyak negeri miskin lainnya di dunia ini yang berupaya mengejar ketertinggalan dengan negara-negara kaya melalui pembangunan ekonomi (Irwan, 1998). Kebijakan dan strategi pembangunan ekonomi ini hampir semuanya disusun 
oleh pemerintah pusat di Jakarta. Bahkan bukan hanya dalam perencanaan, pada kegiatan pelaksanaan proyek pun sangat terasa campur tangan pemerintah pusat. Hampir semua kementerian memiliki program dan proyek di wilayah perdesaan (Marzali, 2012). Hal ini merupakan ciri pemerintahan Orde Baru yang memegang teguh sistem otoritarian yang cenderung sentralistik (Fatmawati, 2018).

Upaya pemerintah Orde Baru untuk mengentaskan kemiskinan di wilayah perdesaan ternyata diuntungkan oleh kondisi perekonomian dunia. Pada tahun 1973-1974 hingga tahun 1981, terjadi kenaikan harga minyak dunia. Bonanza minyak ini memberikan efek tersendiri bagi pemerintah untuk menjalankan program-program pembangunan, termasuk di wilayah perdesaan. Dana yang tersedia cukup banyak kemudian digelontorkan ke wilayah perdesaan. Perluasan peluang kerja di pedesaan telah lama menjadi pusat perhatian dalam perencanaan pembangunan. Beberapa strategi, baik langsung (program padat karya) maupun tidak langsung (pusat-pusat industri, program intensifikasi pertanian) diterapkan. Namun pada sisi lain, peluang kerja di luar sektor pertanian belum mampu menampung kelebihan tenaga perdesaan yang tidak terserap dalam sektor pertanian. Masalah ini semakin diperparah dengan anjloknya harga minyak dunia dan terjadinya resesi ekonomi pada pertengahan tahun 1980an (Effendi, 1995). Kondisi ini pun diuraikan secara apik oleh Criss Manning bahwa intensifikasi pertanian lewat revolusi hijau di Indonesia telah mampu meningkatkan penghasilan petani. Namun dampaknya terhadap peluang kerja bukan pertanian perdesaan masih sangat terbatas. Keengganan petani kaya untuk menanam kembali penghasilan dari sektor pertanian ke sektor produktif di perdesaan diduga sebagai faktor penghambat. Ada kecenderungan kelebihan penghasilan yang dapat dibelanjakan untuk keperluan yang tidak produktif dalam usaha memperkokoh prestise sosial ketimbang diinvestasikan untuk pemupukan modal (Effendi, 1995). Pembangunan pertanian telah memunculkan penggeseran dalam struktur agraris. Tidak dapat diingkari kenyataan bahwa penggeseran dalam struktur agraris mempunyai dampak pada stratifikasi sosial perdesaan. Di perdesaan dijumpai tiga jenis petani yakni petani kaya, sedang, dan miskin serta ada golongan tuna kisma yang kebanyakan masih merupakan buruh tani. Dalam kategorisasi ini, kriteria yang 
dipakai ialah pemilikan/penguasaan tanah. Tekanan demografis dan strategi untuk bertahan mengakibatkan gejala komersialisasi dan komoditasi tanah, sehingga timbul banyak tipe petani antara lain petani pemilik lahan, penyewa, dan penyakap (Kartodirdjo, 1993). Pembangunan pertanian yang mengandalkan penerapan dan penggunaan teknologi (mekanisasi pertanian) yang dibarengi oleh panca usaha tani berupa penggunaan bibit unggul, pengolahan tanah yang baik, penggunaan pupuk, pemberantasan hama, dan irigasi justru memunculkan diferensiasi sosial. Kesejahteraan hanya dinikmati oleh petani pemilik karena mereka mampu menjalankan kegiatan pertanian secara rasional dan efisien. Hasil yang mereka peroleh dapat dimanfaatkan untuk merambah sektor pencarian nafkah di luar pertanian misalnya membuka kios, bengkel dan pertukangan kayu. Sementara petani yang tidak memiliki lahan, mesti mencari pekerjaan lain, karena tenaga mereka sebagai buruh tani terhadap petani pemilih lahan luas tergantikan oleh mesin traktor.

Ditilik dari perspektif pembangunan ekonomi, gagasan pemerintah Orde Baru untuk menjadikan sektor pertanian sebagai penggerak ekonomi rakyat ini membawa maksud untuk membangun perekonomian Indonesia dari desa. Selain bermaksud untuk menciptakan swasembada beras dan ketahanan pangan di wilayah perdesaan, pembangunan pertanian juga dimaksudkan untuk meningkatkan taraf hidup masyarakat. Harus diakui bahwa pembangunan pertanian telah meningkatkan produktivitas dan produksi, dan dalam subsektor tanaman pangan secara nasional telah berhasil mengangkat bangsa berswasembada beras (Saragih, 1992). Namun demikian, sistem pembangunan ekonomi ini juga memunculkan persoalan. Persoalan pertama adalah manfaat pembangunan yang tidak terdistribusi merata, dengan adanya kesenjangan antara petani berlahan luas dengan petani berlahan sempit dan mereka yang tidak memiliki lahan sama sekali. Ketika mesin penggilingan padi belum masuk di wilayah perdesaan, biasanya kaum perempuan bekerja sebagai buruh penumbuk. Mereka datang menumbuk padi untuk menghasilkan beras di rumah tangga petani yang berlahan luas. Kaum perempuan mendapatkan upah 2 liter beras jika menghasilkan 10 liter beras. Tetapi pekerjaan itu hilang ketika mesin penggiling padi sudah dikenal di wilayah perdesaan. Persoalan kedua adalah 
dampak negatif pembangunan pertanian terhadap lingkungan. Penggunaan pupuk yang berlebihan telah membuat lahan persawahan mengalami ketergantungan pada pupuk. Lahan tidak dapat lagi menghasilkan secara maksimal ketika tidak diberi pupuk. Demikian pula dengan penggunaan pestisida yang berlebihan. Para petani pada saat itu belum memiliki pengetahuan yang memadai tentang batas kadar pestisida yang tepat untuk memberantas hama. Hasilnya, ketika sisa air sawah mereka yang mengandung pestisida mengalir ke sungai di sekitar persawahan mereka, maka ini mencemarkan air di daerah aliran sungai yang berbahaya bagi kehidupan makhluk hidup dan hewan ternak yang memperoleh minum dari sungai.

Kebijakan pembangunan top down di wilayah perdesaan yang digaungkan oleh pemerintah Orde Baru juga menyisakan kelemahan. Pertama, pencapaian yang terbatas. Muncul kesulitan dari pemerintah untuk membiayai dan mengawasi semua tenaga ahli dalam bidang pembangunan untuk masuk secara berkelanjutan di wilayah perdesaan. Kedua, proyek-proyek pembangunan pada umumnya membawa serta kemudahan-kemudahan baru ke dalam desa. Tetapi kemudahan- kemudahan tersebut tidak diikuti oleh biaya dan tenaga kerja yang cukup untuk menjalankan dan menjaganya. Ketiga, bantuan pemerintah untuk desa adalah bersifat seragam untuk seluruh Indonesia, tanpa memperhatikan keperluan khas suatu daerah. Keempat, pembangunan yang bersifat top down telah menciptakan ketergantungan penduduk desa pada pemerintah pusat (Marzali, 2012).

Memasuki era reformasi, terjadi perubahan paradigma dalam pelaksanaan pembangunan wilayah perdesaan melalui pendekatan terpadu. Pendekatan ini menempatkan pemerintah sebagai mediator untuk memberikan bimbingan, pengarahan, bantun dan fasilitas yang diperlukan sesuai dengan kemampuan yang tersedia, sedangkan masyarakat diwajibkan untuk ikut berperan aktif dalam wujud inisiatif dan swadaya, seperti gotong royong pada setiap pembangunan, dan pemanfaatan potensipotensi lokal. Pendekatan terpadu dalam proses pembangunan perdesaan yang dimaksud di sini ialah Keterpaduan dalam proses perencanaan dan pelaksanaan pembangunan dengan memperhatikan (1) unsur wilayah dan geografi desa, (2) kaitan fungsional yaitu kegiatan satu sektor dengan sektor yang 
lain tidak berdiri sendiri (3) terjalin keharmonisan antara kebijakan pemerintah dan peran serta masyarakat (4) membagi waktu yang sebaik mungkin sehinga tidak ada kegiatan pembangunan yang tumpang tindih (5) terpadu dalam sasaran dan tujuan yang hendak dicapai bersama (Pahmi, 2010).

Pada era reformasi, pembangunan perdesaan harus dilihat secara kompleks, karena desa telah mengalami berbagai perubahan fundamental dari berbagai aspeknya. Desa tidak dapatlah begitu saja dilihat dari satu klasifkasi atau satu ciri dasar. Desa tidak dapat dilhat lagi hanya sekadar satu kesatuan hidup dengan mengabaikan aspek politiknya, yang mana dalam proses dialektikanya terkadang tidak seiring, dalam arti desa tidak lagi dapat dipahami sebagai wilayah yang tenteram dan harmonis, tetapi terkadang diwarnai oleh gonjang ganjing politik baik yang berskala lokal maupun nasional. Oleh karena itu, pembangunan wilayah perdesaan harus diperhatikan minimal dalam dua aspek yaitu penguatan lokal atas kesatuan budaya desa dan penguatan politik juga tetap atas prakarsa kekuatan-kekuatan lokal.

Dalam kerangka pembangunan desa, harus disadari bahwa masyarakat memiliki peranan penting dalam menyukseskan

pembangunan.

Masyarakat harus ditempatkan sebagai pemrakarsa dalam merencanakan, melaksanakan, dan mengevaluasi kegiatan pembangunan baik fisik maupun non fisik. Masyarakat desa, teruatama petani harus diidentifikasi dengan teliti guna memudahkan konsolidasi perubahan. Hal ini penting, karena pembangunan adalah perubahan mendasar yang memerlukan fondasi yang mapan, yakni kaum tani (Purnomo, 2004).

\begin{tabular}{llr}
\multicolumn{2}{c}{ Paradigma } & kebijakan \\
pembangunan & di era & reformasi \\
menepatkan & pemerintah & sebagai
\end{tabular} fasilitator. Kegiatan pembangunan harus berdasarkan pada kekuatan dan kemampuan masyarakat lokal itu sendiri, yang berarti ketergantungan terhadap pemerintah mulai dibatasi. Dengan demikian, pembangunan masyarakat merupakan proses dinamis yang berkelanjutan dari masyarakat untuk masyarakat untuk mewujudkan keinginan dan harapan hidup yang lebih sejahtera dengan strategi menghindari kemungkinan tersudutnya masyarakat sebagai pengguna akses dari pembangunan regional / daerah atau nasional. Pengertian tersebut mengandung makna betapa pentingnya inisiatif lokal, partisipatif masyarakat 
sebagai bagian dari model-model pembangunan yang dapat menyejahterakan masyarakat desa. Program pembangunan ini tidak berpusat pada birokrasi melainkan berpusat pada masyarakat atau komunitasnya sendiri (Graha, 2009).

Perhatian terhadap pembangunan wilayah perdesaan pada masa reformasi dapat dilihat pada zaman pemerintahan Kabinet Indonesia Bersatu (KIB) yang dikomandoi oleh Presiden Susilo Bambang Yudhoyono dan pada masa pemerintahan Kabinet Kerja yang dikomandoi oleh Presiden Joko Widodo. Pada masa pemerintahan Susilo Bambang Yudhoyono, program pembangunan perdesaan yang didalamnya terkait dengan program penanggulangan kemiskinan dikoordinasikan oleh Tim Nasional Penanggulangan Kemiskinan (TPN2K), yaitu dengan ditetapkannya dua Peraturan Presiden (Perpres) yaitu Perpres No.13 tahun 2009 tentang koordinasi penanggulangan kemiskinan dan Perpres No.15 tahun 2010 tentang percepatan penanggulangan kemiskinan. TNP2K diketuai langsung oleh Wakil Presiden dan mengoordinasikan seluruh kementerian yang menangani kemiskinan. Program penanggulangan kemiskinan di pemerintahan ini ada tiga program, yaitu program berbasis bantuan sosial, program berbasis pemberdayaan masyarakat, dan program berbasis usaha mikro.

Program berbasis bantuas sosial dimaksudkan sebagai upaya untuk pemenuhan hak dasar untuk individu dan rumah tangga miskin yang meliputi bantuan pangan, pendidikan, kesehatan, papan, sanitasi, dan air bersih. Ciri lain dari kelompok program ini adalah mekanisme pelaksanaan kegiatan yang bersifat langsung dan manfaatnya diharapkan dapat dirasakan oleh penerima bantuan (Rustanto, 2015). Program pembangunan ini hanya dilakukan untuk mengatasi secara cepat problem-problem kehidupan masyarakat khususnya masalah kebutuhan hidup sehari-hari. Salah satu bentuk bantuan yang menyasar masyarakat perdesaan ialah Bantuan Langsung Tunai (BLT). Secara historis, negara yag pertama kali menerapakan bantuan langsung tunai terhadap masyarakatnya ialah Brazil. BLT merupakan bantuan pemerintah berjenis uang tunai atau beragam bantuan lainnya baik bersyarat maupun tidak bersyarat. BLT merupakan salah satu kebijakan pemerintahan Kabinet Indonesia Bersatu untuk meringankan beban masyarakat akibat kenaikan harga bahan bakar minyak (BBM) karena 
dikurangi subsidinya oleh pemerintah (Pahmi, 2010).

Bantuan langsung tunai diharapkan oleh pemerintah untuk meningkatkan produktivitas masyarakat. Tetapi banyak kalangan yang pesimis akan hal tersebut. Aviliani dan Sri Adiningsih justru menilai bahwa BLT hanya memanjakan dan menciptakan mentalitas pengemis bagi masyarakat, bahkan cenderung memperlemah semangat kerja masyarakat. Sementara Sri Adiningsih berpendapat bahwa pemberian BLT kepada masyarakat merupakan suatu kebijakan yang tidak mendidik. Keduanya malah berpendapat bahwa sebaiknya dana yang dikucurkan untuk BLT justru lebih bermanfaat ketika dialihkan untuk membiayai pembangunan sarana dan prasarana perdesaan (Hasbullah, 2009). Lebih lanjut Selviana menguraikan berbagai kelemahan dari program BLT yakni:

a. Kebijakan BLT bukan kebijakan yang efektif dan efisien untuk menyelesaiakan kemiskinan di Indonesia, ini dikarenakan kebijakan ini tidak mampu meningkatkan derajat dan tingkat kesejahteraan mayarakat miskin

b. Efektifitas dan efisiensi penggunaan dana BLT yang tidak dapat diukur dan diawasi karena lemahnya fungsi pengawasan pemerintahan terhadap kebijakan tersebut

c. Validitas data masyarakat miskin yang diragukan sehingga akan berdampak pada ketepatan pemberian dana BLT kepada masyarakat yang berhak.

d. Kebijakan BLT memiliki kecenderungan menjadi pemicu konflik sosial di masyarakat

e. Peran aktif masyarakat yang kurang/minim, sehingga optimalisasi kinerja program yang sulit direalisasikan

f. Dari sisi keuangan negara, kebijakan BLT merupakan kebijakan yang bersifat menghambur-hamburkan uang negara karena kebijakan tersebut tidak mampu menyelesaiakan masalah kemiskinan secara berkelanjutan dan tidak mampu menstimulus produktifitas masyarakat miskin

g. Data yang di berikan kepada pusat tidak sesuai dengan kenyataan yang terjadi dan data tersebut adalah data yang di gunakan pada tahun-tahun sebelumnya dan tidak adanya pembaharuan data (Selviana dkk, 2016). 
Ketika Indonesia memasuki era kabinet kerja yang dinahkodai oleh Joko Widodo dan Muh.Jusuf Kalla, gagasan dan gerakan pembangunan wilayah perdesaan semakin digelorakan sebagaimana yang tertuang dalam Nawacita. Salah satu dari sembilan agenda prioritas pemerintahan Jokowi-JK yang tertuang dalam Nawacita adalah upaya membangun Indonesia dari pinggiran dengan memperkuat da erah dan desa dalam kerangka negara kesatuan. Jika selama ini tata kelola pemerintahan negara lebih didominasi oleh regim sektoral dan keuan-gan, pemerintahan Jokowi-JK berkomitmen untuk mensinergikan tata kelola pemerintahan Indonesia sebagai satu kesatuan sistem yang tidak terfragmentasi. Hal tersebut diwujudkan melalui penye-lenggaraan politik desentralisasi di pusat dengan mengimplementasikan regim desentralisasi sebagai ujung tombak pengelolaan pemerintahan negara. Pada konteks inilah posisi dan kedudukan desa men-jadi strategis yakni sebagai self-governing commu-nity "kesatuan masyarakat hukum" yang memiliki peran strategis, bahkan tampil sebagai panggung utama di dalam mendorong pembangunan ekonomi Indonesia (Palupi, 2016).
Perhatian terhadap pembangunan perdesaan diwujudkan oleh pemerintah dengan membentuk Kementerian Desa, Pembangunan Daerah Tertinggal dan Transmigrasi. Program pembangunan perdesaan ditempuh dengan cara menyediakan anggaran khusus untuk mendanai kegiatan pembangunan di wilayah perdesaan. Eko Putro Sandjojo selaku menteri yang menangani pembangunan pedesaan pada masa kabinet kerja (27 Juli 2016-20 Oktober 2019) menjelaskan bahwa capaian pembangunan di desa yang menjadi sejarah baru yakni jalan desa dibangun sepanjang 191.600 kilometer, jembatan sepanjang $\quad 1.140 .378$ kilometer, kemudian pasar desa sebanyak 8.983 unit, BUMDes sebanyak 37.830 unit kegiatan Kemudian penahan tanah sebanyak 192.974 unit, MCK 240.587 unit, poliklinik desa (polindes) 9.692 unit, selanjutnya sumur 45.109 unit, posyandu 24.820 unit, embung padi 4.175 unit dan lain sebagainya (Azzura, 2019).

\section{Urgensi Modal Sosial Dalam} Pembangunan Perdesaan: Sebuah Studi di Desa Tompobulu

Indonesia sebagai negara berkembang yang terus berbenah dan menggalakkan pembangunan, termasuk pembangunan wilayah perdesaan di 
berbagai sektor sangat mengandalkan modal sosial sebagai basis struktur dalam menggerakkan masyarakat untuk ikut serta berpartisipasi aktif dalam aktivitas pembangunan. Modal sosial menekankan pentingnya kebersamaan masyarakat untuk memperbaiki kualitas hidup bersama dan melakukan perubahan yang lebih baik serta penyesuaian secara terus menerus (Azhari, 2018). Oleh karena itu, modal sosial ditempatkan sebagai salah satu unsur utama dalam menggerakkan kolektifitas, pergerakan gagasan, saling mempercayai (trust) dan saling menguntungkan demi mewujudkan kemajuan dan kemakmuran rakyat. Hal ini sesuai dengan pendapat Francis Fukuyama bahwa modal sosial memiliki peranan penting dalam menggerakkan fungsi dan kekuatan kehidupan masyarakat moderen. Modal sosial merupakan syarat yang wajib dipenuhi untuk pengembangan sumber daya manusia, pembangunan politik, ekonomi, dan sosial budaya kemasyarakatan (Fukuyama, 1999). Modal sosial pun kemudian dianggap sebagai kerangka teoritis yang bermanfaat dalam paradigma pembangunan inklusif berkelanjutan. Posisi modal sosial menjadi penting untuk disorot mengingat paradigma pembangunan yang diberlakukan tersebut lebih bersifat bottom up ketimbang top down (Fathy, 2019).

Modal sosial dalam pandangan Fukuyama adalah kapabilitas yang muncul dari kepercayaan umum di dalam sebuah tatanan masyarakat atau elemenelemen khusus dari masyarakat. Konsepsi modal sosial juga dipersepsikan oleh Fukuyama sebagai sekumpulan norma dan nilai informal yang merupakan kepemilikan bersama di antara para anggota suatu komunitas yang memungkinkan munculnya jalinan kerjasama (Fukuyama, 1999). Lebih lanjut, Robert Putnam menerangkan secara apik bahwa modal sosial merupakan penampilan organisasi sosial, misalnya kepercayaan, norma-norma, jaringan yang dapat memperbaiki efisiensi masyarakat dengan memfasilitasi adanya kordinasi dan kerjasama bagi keuntungan bersama. Modal sosial dalam hal pembangunan masyarakat perdesaan memiliki peranan yang penting dalam upaya transformasi sosial holistik menuju masyarakat perdesaan yang berkeadaban (Suharto, 2005).

Menurut Santosa dan Priyono, upaya untuk mendorong terjadinya transformasi sosial diperlukan aspek kemandirian yang kuat. Hal ini 
disebabkan agar masyarakat yang diberdayakan tidak mengalami perubahan yang menuju distabilitas yang dapat mengganggu sistem secara keseluruhan. Untuk mendukung pemberdayaan juga perlu kesiapan faktor internal agar perubahan yang terjadi tidak bertentangan dengan kehendak masyarakat. pemberdayaan masyarakat juga tidak hanya menekankan faktor ekonomi saja, namun perlu juga memperhatikan faktor politik, ideologi, budaya dan ekologi. Hendaknya pemberdayaan masyarakat dipahami sebagai upaya terpadu untuk keberdayaan komunitas lokal melalui transformasi sosial yang berkelanjutan (Santosa, 2017). Transformasi sosial dapat dilakukan dengan pengembangan masyarakat sebagai sebuah usaha praktis untuk mengarahkan masyarakat kepada kemandirian, sehingga mereka mampu menganalisa sendiri isu-isu sosial serta dapat menemukan solusi atas permasalahan mereka (Cahyono, 2014). Transformasi sosial melalui desa membangun diharapkan dapat mendukung upaya pencapaian sasaran pembangunan desa dan kawasan pedesaan, yakni mengentaskan 5000 Desa Tertinggal dan meningkatkan sedikitnya 2000 Desa Mandiri (Setyowati, 2019).
Agar transformasi sosial yang dikemas dalam program pembangunan perdesaan dapat berjalan dengan baik, maka perlu diperhatikan unsur-unsur modal sosial yang sudah lama berkembang dalam kehidupan mereka. Sebagaimana yang dikemukakan oleh Suparman Abdullah bahwa Setiap komunitas memiliki sumber dan potensi modal sosial yang dapat diakses dan dimanfaatkan oleh anggotanya (Abdullah, 2013). Pada tingkat masyarakat perdesaan, sebetulnya sudah tersedia modal sosial yang dapat dielaborasi untuk kepentingan pembangunan yang bertujuan untuk mencapai kesejahteraan masyarakat. Hal ini penting karena karakter modal sosial yang dimiliki masyarakat perdesaan dapat memperkuat ikatan dan solidaritas internal, sekaligus mendorong perluasan jaringan ke lingkungan yang lebih luas di luar lingkungan kehidupan mereka. Untuk menguraikan tentang arti penting modal sosial dalam pembangunan, maka dalam pembahasan ini akan diketengahkan sebuah pengalaman penelitian di Desa Tompubulu. Desa Tompobulu merupakan desa pegunungan yang terletak di Kecamatan Bulupoddo, Kabupaten Sinjai, Provinsi Sulawesi Selatan. Ada beberapa unsur modal sosial yang memiliki peranan 
untuk kesuksesan kegiatan pembangunan di Desa Tompobulu, antara lain:

1. Kepercayaan (trust). Kegiatan pembangunan yang dilaksanakan di Desa Tompo Bulu salah satunya ialah pembangunan jembatan gantung yang melintasi aliran Sungai Tangka. Jembatan tersebut merupakan penghubung antara masyarakat yang bermukim di Desa Tompobulu, Kabupaten Sinjai dengan masyarakat yang bermukim di Desa Bana, Kabupaten Bone. Meskipun diketahui mereka terpisah secara wilayah administratif, tetapi masyarakat dari kedua desa ini masing-masing masih memiliki ikatan kekerabatan. Berdasarkan informasi yang diperoleh, pembangunan jembatan ini diprakarsai oleh Pemerintah Daerah Kabupaten Sinjai bekerjasama dengan Kodim 1424 Sinjai. Tingkat kepercayaan masyarakat Desa Tompobulu terhadap pemerintah setempat menjadi salah satu faktor penting dalam terwujudnya pembangunan jembatan tersebut. Mahmuddin selaku Kepala Desa Tompobulu menyadari bahwa kepercayaan yang diberikan oleh warga untuk memimpin desa ini mesti dia pertanggungjawabkan, sebab kepercayaan tersebut dibarengi dengan ekspektasi yang tinggi dari masyarakat untuk mewujudkan program-program pembangunan yang akan bersentuhan langsung dengan masyarakat. Demikian pula, pemerintah setempat telah memberikan kepercayaan yang tinggi kepada masyarakat untuk merawat jembatan tersebut sehingga dapat dimanfaatkan secara berkelanjuntan untuk menggerakkan roda perekonomian.

2. Nilai dan Norma

Salah satu sistem nilai yang masih bertahan pada masyarakat Desa Tompobulu ialah nilai gotong royong. Dalam hal urusan yang menyangkut kepentingan bersama misalnya pembangunan dan pemeliharaan masjid, perbaikan jalan desa, perbaikan jalur irigasi, perbaikan kantor desa, dan perbaikan pos ronda. Kegiatan gotong royong diwujudkan dengan kerja bakti setiap Hari Ahad, terutama ketika tiba Bulan Juli dan Agustus untuk menyambut hari ulang tahun kemerdekaan Republik Indonesia. Kegiatan kerja bakti biasanya dimulai pada pagi hari sekitar pukul 07.00, setelah masyarakat mengurusi hewan ternak mereka sampai pada pukul 11.00. Kegiatan kerja bakti itu diikuti oleh segenap warga laki-laki baik orang tua maupun mereka yang masih muda. Sementara kaum perempuan yang dikordinir oleh istri Kepala Desa dibantu 
oleh istri Kepala Dusun selaku tim penggerak PKK bertugas untuk menyediakan makanan ala kadarnya, bisanya singkong rebus, pisang rebus atau pisang goreng dan seduhan air kopi dan teh.

3. Jaringan sosial

Untuk melaksanakan kegiatan pembangunan di Desa Tompobulu, pemerintah setempat menyadari akan pentingnya kerjasama antar elemen masyarakat. untuk pembangunan, misalnya pembangunan Masjid, maka memerlukan dana yang cukup besar. Kalau hanya mengandalkan dana dari masyarakat, maka itu belum mampu untuk menutupi dana pembangunan tersebut. Untuk mendapatkan dana maka biasanya mengharapkan bantuan dari berbagai pihak dalam hal ini dari kalangan pengusaha, pemerintah daerah, atau sumbangan pribadi dari beberapa pejabat di tingkat Kabupaten. Untuk mendapatkan bantuan atau sumbangan tersebut, maka kepala desa atau tokoh masyarakat harus memiliki kemampuan untuk membangun komunikasi dan jaringan sosial dengan pihak-pihak yang dimaksud. Dari segi tenaga kerja, masyarakat yang berprofesi sebagai tukang batu dan tukang kayu juga berusaha untuk meminta bantuan kepada rekan-rekan yang memiliki keahlian dalam bidang pertukangan, meskipun itu berasal dari desa lain.

4. Partisipasi

Untuk mewujudkan keberhasilan pembangunan, inisiatif dan kreatifitas dari anggota masyarakat yang lahir dari kesadaran dan tanggung jawab sebagai manusia yang hidup bermasyarakat dan diharapkan tumbuh berkembang sebagai suatu partisipasi. Sehubungan dengan partisipasi masyarakat dalam pembangunan. Partisipasi merupakan keterlibatan masyarakat secara aktif masyarakat dapat juga keterlibatan dalam proses penentuan arah, strategi kebijaksanaan pembangunan yang dilaksanakan pemerintah. Hal ini terutama berlangsung dalam proses politik dan juga proses sosial, hubungan antara kelompok kepentingan dalam masyarakat sehingga demikian mendapat dukungan dalam pelaksanaannya (Pemkab Buleleng, 2017). Lebih lanjut Histiraluddin menjelaskan bahwa partisipasi lebih pada alat sehingga dimaknai partisipasi sebagai keterlibatan masyarakat secara aktif dalam keseluruhan proses kegiatan, sebagai media penumbuhan kohesifitas antar masyarakat, masyarakat dengan pemerintah juga menggalang tumbuhnya rasa memiliki dan tanggung jawab pada 
program yang dilakukan (Handayani, 2006).

Terkait dengan partisipasi masyarakat dalam pembangunan di wilayah Desa Tompobulu, maka hal tersebut dapat dilihat pada tahap perencanaan, pelaksanaan, dan evaluasi. Perencanaan dilakukan dengan cara mengundang masyarakat untuk datang ke balai desa untuk menghadiri musyawarah mufakat dalam rangka menggali aspirasi dan informasi dari masyarakat mengenai prioritas utama yang akan dibangun. Setelah ada kesepakatan mengenai prioritas utama pembangunan, maka tahap selanjutnya ialah melaksanakan kegiatan pembangunan. Biasanya ketika pembangunan itu tidak diberikan kepada pihak ketiga, dalam hal ini pengusaha/kontraktor bangunan, maka tahapan pengerjaan diserahkan kepada masyarakat setempat. Namun, menjadi kelaziman di desa ini, kalaupun ada pihak perusahaan yang terlibat dalam proses penyelesaian pembangunan fisik, maka tenaga kerjanya direkrut dari masyarakat setempat. Setelah pembangunan dianggap rampung, maka evaluasi itu diserahkan pula kepada masyarakat setempat. Misalnya dalam hal pembangunan irigasi, ketika masyarakat sudah menyatakan bahwa irigasi tersebut sudah layak untuk digunakan dan telah memenuhi standar dalam hal ini daya tahan dan kekuatan bangunan, maka pemerintah desa menganggap kegiatan tersebut telah selesai dan hal itu kemudian dilaporkan kepada tingkat selanjutnya.

\section{Kesimpulan}

Kekuatan utama dalam pembangunan perdesaan terletak pada masyarakat setempat. Masyarakat tidak dapat lagi ditempatkan sebagai objek pembangunan, tetapi masyarakat harus diposisikan sebagai subjek pembangunan, dalam hal ini kegiatan perencanaan pembangunan, pelaksanaan sampai pada tahap evaluasi harus melibatkan masyarakat, sedangkan pemerintah hanya sebagai fasilitator. Tampilnya masyarakat sebagai subjek pembangunan, khususnya di Desa Tompobulu, karena masyarakat di desa ini memiliki modal sosial yang masih kuat. Fenomena tersebut semakin memperkuat konsep pembangunan yang bersifat botton up, sehingga konsep ini layak untuk dipertahankan dalam menggerakkan pembangunan di wilayah perdesaan untuk mewujudkan pembangunan yang merata menuju masyarakat adil dan makmur sebagaimana yang tertuang dalam 
Pancasila dan Undang-Undang Dasar 1945.

\section{Daftar Pustaka}

Abdullah, S. (2013). Potensi Dan

Kekuatan Modal Sosial Dalam Suatu

Komunitas. Socius, XII.

Angelis, M. . dkk. (2016). Petaka

Neoliberalisme. Malang: Intrans Publishing.

Azhari, F. dan M. K. M. (2018). Peran Modal Sosial Dalam Pengembangan Jaringan Usaha Kecil Menengah (Studi Kasus pada Rumah Makan Padang). Jurnal Administrasi Bisnis, 59(1).

Azzura, S. . (2019). Mendes Eko: Pembangunan Desa Era Jokowi-JK Cetak Sejarah. Retrieved December 25, 2019, from https://www.merdeka.com/uang/m endes-eko-pembangunan-desa-erajokowi-jk-cetak-sejarah.html

Baswir, R. (1999). Pembangunan Tanpa Perasaan. Jakarta: ELSAM.

Budiman, A. (1996). Teori Pembangunan Dunia Ketiga. Jakarta: Gramedia.

Cahyono, B. (2014). Peran Modal Sosial

Dalam Peningkatan Kesejahteraan

Petani Tembakau Di Kabupaten

Wonosobo. Ekobis, 15(1).

Chaniago, A. . (2012). Gagalnya Pembangunan: Membaca Ulang Keruntuhan Orde Baru. Jakarta:
LP3ES.

Effendi, T. . (1995). Sumber Daya Manusia, Peluang Kerja, dan Kemiskinan. Yogyakarta: Tiara Wacana.

Fahruddin, A. (2012). Pengantar Kesejahteraan Sosial. Bandung: Refika Aditama.

Fathy, R. (2019). Modal Sosial: Konsep, Inklusivitas dan Pemberdayaan Masyaraka. Jurnal Pemikiran Sosiologi, 6(1).

Fatmawati, N. . (2018). Desentralisasi Asimetris, Alternatif Bagi Masa Depan Pembagian Kewenangan di Indonesia. Madani Jurnal Politik Dan Sosial Kemasyarakatan, 10(3).

Fukuyama, F. (1999). The End Of History and The Last Man: Kemenangan Kapitalisme dan Demokrasi Liberal. Yogyakarta: Qalam.

Graha, A. . (2009). Pengembangan Masyarakat Pembangunan Melalui Pendampingan Sosial Dalam Konsep Pemberdayaan Di Bidang Ekonomi. Jurnal Ekonomi Modernisasi, 5(2).

Handayani, S. (2006). Perlibatan Masyarakat Marginal Dalam Perencanaan dan Penganggaran Partisipasi. Surakarta: Kompip Solo. Haridison, A. (2017). Modal Sosial Dalam Pembangunan. JISPAR:Jurnal Ilmu Sosial Dan Pemerintahan, 4. 
Hasbullah, M. . (2009). Studi Pemahaman

Opini Publik Dalam Upaya Peningkatan Strategi Kehumasan Badan Pusat StatistikBUKU 02iiStudi Pemahaman Opini Publik Dalam Upaya Peningkatan Strategi Kehumasan Badan Pusat Statistik. Jakarta: Badan Pusat Statistik.

Hutagalung, S. . (2012). Optimalisasi Pembangunan Desa Melalui Pelatihan Perencanaan

Pembangunan Desa Bagi Sekretaris Desa. In Seminar Hasil-Hasil Penelitian dan Pengabdian Kepada Masyarakat- Dies Natalis FISIP Unila Tahun 2012. Bandar Lampung: Lembaga Penelitian dan Pengabdian Kepada Masyarakat UNILA.

Irwan, A. (1998). Bad Governance dan Keruntuhan Ekonomi Indonesia. Jurnal UNISIA, 21(4).

Jamal, E. (2009). Membangun

Momentum Baru Pembangunan

Pedesaan di Indonesia. Jurnal

Litbang Pertanian, 28(2).

Jamaluddin, A. . (2016). Sosiologi

Pembangunan. Bandung: Pustaka Setia.

Kartodirdjo, S. (1993). Pembangunan

Bangsa. Yogyakarta: Aditya Media.

Marzali, A. (2012). Antropologi dan Kebijakan Publik. Jakarta: Kencana. Mosher, A. . (1969). Menggerakkan dan
Membangun Pertanian. Jakarta: C.V.Yasaguna.

Muryanto dkk. (2019). Akuntabilitas Perumusan Kebijakan Publik Dalam Musyawarah Perencanaan

Pembangunan (MUSRENBANG) (Studi pada Badan Perencanaan dan Pembangunan Daerah Kabupaten Malang). Madani Jurnal Politik Dan Sosial Kemasyarakatan, 11(1), 7485.

Pahmi. (2010). Perspektif Baru Antropologi Pedesaan. Yogyakarta: Galang Press.

Palupi, S. dkk. (2016). Buku Panduan Pelaksanaan Undang-Undang Desa Berbasis Hak. Jakarta: Lakpesdam PBNU.

Pemkab Buleleng. (2017). Teori Partisipasi : Konsep Partisipasi Masyarakat Dalam Pembangunan Menurut Para Ahli. Retrieved December 25, 2019, from https://bulelengkab.go.id/detail/art ikel/teori-partisipasi-konseppartisipasi-masyarakat-dalampembangunan-menurut-para-ahli10

Purnomo, M. (2004). Pembaruan Desa: Mencari Bentuk Penataan Produksi Desa. Yogyakarta: Lappera Pustaka Utama.

Rustanto, B. (2015). Menangani 
Kemiskinan. Bandung: Rosda.

Santosa, I. (2017). Dinamika Masyarakat Pedesaan Dalam Perspektif Sosiologis. Yogyakarta: Pustaka Pelajar.

Saragih, B. (1992). Mengembangkan Keswadayaan Masyarakat di Daerah Pedesaan. In Abdullah Syarwani dan Metiah Gani Rochman (Ed.), Pengembangan Swadaya Nasional. Jakarta: LP3ES.

Selviana dkk. (2016). Bantuan Langsung Tunai. Jurnal Equilibrum, 3(2).

Setyowati, E. (2019). Tata Kelola

Pemerintahan Desa Pada Perbedaan

Indeks Desa Membangun (IDM):

Studi Tiga Desa Di Kabupaten Malang. JISPO, 9(2).

Suharto, E. (2005). Membangun

Masyarakat Memberdayakan Rakya:

Kajian Strategis Pembangunan

Kesejahteraan Sosial dan Pekerjaan

Sosial. Bandung: Refika Aditama.

Sumodingrat, G \& Wulandari, A. (2016).

Membangun Indonesia Dari Desa.

Yogyakarta: Media Pressindo.

Tjiptoherijanto, P. (1997). Pengentasan

Kemiskinan Melalui Pembangunan Jaringan Ekonomi Pedesaan. Jurnal Populasi, 3(2).

Tjokrowinoto, M. (2004). Pembangunan, Dilema dan Tantangan. Yogyakarta: Pustaka Pelajar.
Usman, S. (2010). Pembangunan dan Pemberdayaan Masyarakat. Yogyakarta: Pustaka Pelajar.

Warjio. (2016). Politik Pembangunan: Paradoks, Teori, Aktor, dan Ideologi. Jakarta: Kencana.

Winarno, B. (2013). Etika Pembangunan. Yogyakarta: Center for Academic Publishing Service.

Yuliati, Y. dan Mangku Poernomo. (2003). Sosiologi Pedesaan. Yogyakarta: Lappera Pustaka Utama. Yustika, A.E. (2003). Negara VS Kaum Miskin. Yogyakarta: Pustaka Pelajar. 